\title{
Pelatihan dan Pendampingan Penulisan Artikel Ilmiah pada Guru Sekolah Dasar di Kecamatan Air Periukan Kabupaten Seluma Provinsi Bengkulu
}

\section{Workshop and Mentoring of Scientific Writing on Elementary School Teacher in Air Periukan Subdistrict, Seluma Regency and Bengkulu Province}

\author{
Danner Sagala $^{1 *}$, Supriyono $^{2}$, Dodo Sutardi ${ }^{3}$, Prihanani $^{1}$ \\ ${ }^{1}$ Prodi Agroteknologi, Fakultas Pertanian, Universitas Prof Dr Hazairin SH, J1 Jend Sudirman No 185 Bengkulu, \\ Indonesia \\ ${ }^{2}$ Prodi Pendidikan Geografi, Fakultas Keguruan dan Ilmu Pendidikan, Universitas Prof Dr Hazairin SH, J1 Jend A \\ Yani No 1 Bengkulu, Indonesia \\ ${ }^{3}$ Prodi Pendidikan Bimbingan dan Konseling, Fakultas Keguruan dan Ilmu Pendidikan, Universitas Prof Dr Hazairin \\ SH, Jl Jend A Yani No 1 Bengkulu, Indonesia
}

\begin{tabular}{l}
\hline Info Artikel \\
\hline Diterima 15 Juni 2019 \\
Ditelaah 8 Juli 2019 \\
Disetujui 26 Agustus 2019 \\
Tersedia daring $30 \quad$ Oktober \\
2019 \\
*Penulis untuk korespondensi \\
danner_10@ yahoo.com \\
\hline \\
Kata Kunci: \\
Karir \\
Pangkat Pegawai Negeri Sipil \\
Pendidik \\
Pengabdian pada Masyarakat \\
Publikasi
\end{tabular}

\begin{tabular}{l} 
ABSTRAK \\
\hline Kegiatan pengabdian pada masyarakat ini bertujuan untuk membantu para guru \\
memahami konsep dan proses publikasi artikel ilmiah pada jurnal ilmiah. Target dari \\
program ini adalah guru mampu menulis draft artikel dan didampingi hingga naskah siap \\
untuk dikirimkan ke jurnal ilmiah. Peserta merupakan anggota dari Kelompok Kerja \\
Guru di Kecamatan Air Periukan, Kabupaten Seluma, Provinsi Bengkulu. Pelatihan \\
dilaksanakan dengan metode pembelajaran partisipatif dan pendampingan. Hasil \\
pengamatan selama kegiatan menunjukkan bahwa guru memiliki animo yang tinggi \\
untuk dilatih mempublikasikan artikel ilmiah. Namun, animo ini belum diiringi dengan \\
jumlah naskah yang dihasilkan. Ketidakbiasaan mempublikasikan artikel ilmiah \\
membuat publikasi artikel ilmiah menjadi suatu "momok" bagi guru dan menurunkan \\
kepercayaan-diri guru untuk mempublikasikan karya ilmiah di jurnal ilmiah yang \\
ditelaah. Program pelatihan dan pendampingan ini telah menghasilkan 12\% darft artikel \\
dari 52 orang peserta. Hal ini menunjukkan perlunya diteruskan pelatihan dan \\
pendampingan serupa bagi guru-guru agar semakin banyak guru yang dapat \\
mempublikasikan karya ilmiahnya di jurnal ilmiah.
\end{tabular}

Keywords:

Career

Civil servant grade

Community service

Educator

Publication

\section{ABSTRACT}

This community service was aimed to help teachers understand the concepts and processes of publicizing scientific articles in scholarly journals. The target of the program was the teachers are able to compile a manuscript and be accompanied until it is ready to be sent to the scholarly journal. The participants were members of the Air Periukan Subdistrict Teacher Working Group in Seluma District, Bengkulu Province. The training was carried out with participatory lecturing and mentoring methods. The results of observations on the implementation of the program through evaluation showed that the teachers had a high interest in being trained to publish scientific articles. However, high interest has not been followed by the number of manuscripts produced. The unfamiliarity of the publication of scientific articles has led to scientific publications becoming a "scourge" and reducing the teacher's self-confidence to publish their scholarly article in peer-reviewed scientific journals. This program produced $12 \%$ of article drafts from 52 participants. This concluded that the program has to be continued so that the scientific work of teachers published in the scholarly journals will increase.
\end{abstract}

ISSN 2685-0354 (Media Online). Diterbitkan oleh Universitas Prof. Dr. Hazairin, SH. Ini merupakan jurnal bebas akses di bawah lisensi Creative Commons Atribution 4.0 International (https://creativecommons.org/licenses/by/4.0 


\section{PENDAHULUAN}

Salah satu sub unsur kegiatan yang diperhitungkan di dalam angka kredit tugas fungsional guru menurut Peraturan Menteri Negara Pendayagunaan Aparatur Negara dan Reformasi Birokrasi (Permenpan-RB) Nomor 16 Tahun 2009 tentang Jabatan Fungsional Guru dan Angka Kreditnya adalah publikasi artikel ilmiah pada majalah/jurnal ilmiah. Sub unsur publikasi artikel ilmiah masuk di dalam unsur pengembangan keprofesian berkelanjutan. Hal ini dapat diartikan bahwa profesi guru tidak dapat dilepaskan dari kegiatan penelitian untuk menghasilkan suatu karya ilmiah atau inovasi dalam bentuk publikasi artikel ilmiah. Menurut Bem (2003), kegiatan selanjutnya setelah melaksanakan penelitian adalah mempublikasikan hasil penelitian untuk diketahui oleh khalayak. Hoogenboom dan Manske (2012) menyatakan bahwa penelitian hanya merupakan permulaan dari kegiatan ilmiah. Peneliti harus menuliskan hasil penelitian tersebut dan mempublikasikannya untuk diketahui profesi lain hingga memiliki dampak pada masyarakat. Namun, Undang-undang Nomor 14 Tahun 2005 tentang Guru dan Dosen tidak mendefinisikan penelitian sebagai salah satu tugas guru.

Survei awal dilakukan pada guru-guru di Kecamatan Air Periukan, Kabupaten Seluma, Provinsi Bengkulu untuk menentukan kegiatan pengabdian pada masyarakat apa yang dibutuhkan oleh para guru. Hasil survei awal memberikan gambaran kebutuhan terhadap pengetahuan penulisan artikel ilmiah bagi guru-guru. Hasil penelusuran literatur menunjukkan bahwa hal demikian juga terjadi pada guru di beberapa daerah lainnya (Farisi, 2011; Ilfiandra, Suherman, Akhmad, Budiamin, \& Setiawati, 2016; Ismail, 2010; Noorjannah, 2014; Nurhayati, 2015).

Ketiadaan fungsi penelitian pada definisi guru di dalam Undang-undang Nomor 14 Tahun 2005 tentang Guru dan Dosen menyebabkan guru tidak terbiasa melakukan penelitian hingga mempublikasikan artikel ilmiah pada jurnal ilmiah. Hal ini juga terlihat dari persyaratan kenaikan pangkat yang mana sub unsur publikasi artikel ilmiah tidak menjadi syarat wajib sejak pangkat terendah. Kenaikan pangkat guru dari IIIA hingga IVA tidak mewajibkan adanya sub unsur publikasi artikel ilmiah pada jurnal ilmiah. Kegiatan publikasi artikel ilmiah menjadi syarat wajib bagi kenaikan pangkat guru dari IVA ke IVB hingga pangkat paling tinggi. Para guru tidak terbiasa dengan penulisan artikel ilmiah untuk dipublikasikan pada jurnal ilmiah. Sebelum adanya Permenpan-RB No. 16 Tahun 2009, publikasi artikel ilmiah pada jurnal/majalah ilmiah tidak merupakan salah satu syarat wajib kenaikan pangkat/golongan dari Pembina/IVA ke pangkat yang lebih tinggi. Keputusan Menteri Pendayagunaan Aparatur Negara Nomor 084 Tahun 1993 mensyaratkan karya tulis ilmiah untuk kenaikan pangkat dari IVA ke atas namun bukan pubikasi artikel ilmiah pada jurnal ilmiah. Publikasi artikel pada jurnal ilmiah harus melalui proses telaah (review) dari ahli yang memiliki keilmuan yang relevan dengan topik artikel yang dikirim kepada editor jurnal ilmiah. Editor jurnal ilmiah juga terlebih dahulu menilai kelayakan naskah yang dikirim oleh penulis sebelum diteruskan ke proses telaah oleh ahli. Selain itu, guru memiliki tugas/fungsi hanya di pengajaran sehingga tidak memiliki kebiasaan meneliti dan menulis artikel ilmiah sebagaimana dilakukan oleh dosen. Padahal Ecarnot, Seronde, Chopard, Schiele, dan Meneveau (2015) menyatakan bahwa menulis artikel ilmiah membutuhkan latihan dan kebiasaan. Penulis baru akan kesulitan dalam menganalisis data dan mendiskusikannya secara terstruktur di dalam suatu manuskrip. Hoogenboom dan Manske (2012) menyimpulkan bahwa penulis membutuhkan upaya yang substantif untuk dapat menghasilkan artikel ilmiah yang baik.

Kurangnya kemampuan para guru di lingkungan Kelompok Kerja Guru (KKG) Kecamatan Air Periukan dan guru-guru di daerah lainnya dalam menulis artikel ilmiah mempengaruhi peningkatan karir para guru yaitu kepangkatan dan jabatan fungsional. Umumnya, guru yang sudah mencapai pangkat IVA tidak mengusulkan kenaikan pangkat ke IVB karena tidak dapat memenuhi persyaratan wajib publikasi artikel ilmiah di jurnal ilmiah. Sementara Dhermawan, Sudibya, dan Utama (2012) dan Suwati (2013) menyimpulkan karir kepangkatan akan mempengaruhi gaji dan akhirnya gaji akan mempengaruhi motivasi kerja.

Para guru di lingkungan KKG Kecamatan Air Periukan Seluma belum pernah memperoleh pendampingan penulisan artikel ilmiah untuk publikasi pada jurnal ilmiah. Aisyah dan Mahanani (2017) menyarankan bahwa peningkatan kemampuan guru dalam menulis artikel ilmiah masih perlu untuk ditingkatkan. Oleh karena itu, diperlukan suatu metode dalam meningkatkan kemampuan menulis para guru selain dengan cara pelatihan. Kegiatan pelatihan yang disertai dengan pendampingan penulisan artikel ilmiah untuk dipublikasikan pada jurnal ilmiah terhadap guru perlu dilakukan yang dimulai dari konsep (draft) hingga siap untuk dikirim ke jurnal ilmiah.

Tujuan dari kegiatan ini adalah untuk membantu para guru memahami konsep dan proses publikasi artikel ilmiah pada jurnal ilmiah. Tujuan lainnya adalah untuk melatih para guru menyusun naskah ilmiah dari hasil penelitian yang dapat dilakukan oleh guru setiap hari yaitu penelitian tindakan kelas. Oleh karena itu, target dari program ini adalah guru mampu menulis draft artikel dan didampingi hingga naskah siap untuk dikirimkan ke jurnal ilmiah. 


\section{METODE}

Kegiatan pengabdian pada masyarakat di lingkungan KKG Kecamatan Air Periukan Kabupaten Seluma Provinsi Bengkulu dilaksanakan sejak Bulan Februari hingga Juli 2018. Tim pengabdi Lembaga Penelitian dan Pengabdian pada Masyarakat Universitas Prof. Dr. Hazairin, SH menjadi pelaksana kegiatan, KKG Kecamatan Air Periukan sebagai mitra. Peserta yang mengikuti kegiatan adalah guru-guru anggota KKG Kecamatan Air Periukan. Kegiatan dilaksanakan dalam bentuk pelatihan dan pendampingan yang bersifat partisipatif (Tabel 1).

\section{Persiapan Kegiatan}

Beberapa persiapan yang dilakukan adalah:

1. Survei kebutuhan mitra

Survei awal dilakukan terhadap mitra untuk mengetahui permasalahan mitra. Data dari survei awal menjadi dasar untuk melakukan analisis situasi. Survei dilakukan dalam bentuk wawancara dengan pengurus KKG Kecamatan Air Periukan.

2. Penentuan masalah prioritas dan topik kegiatan

Beberapa permasalahan yang ditemukan dianalisis untuk menentukan permasalahan prioritas yang akan diselesaikan dengan solusi yang ditawarkan untuk menyelesaikan permasalahan tersebut. Masalah prioritas yang dipilih bersama mitra adalah peningkatan kemampuan menulis artikel ilmiah untuk publikasi pada jurnal ilmiah (Tabel 1).

Tabel 1. Kegiatan yang dilaksanakan pada program pengabdian pada masyarakat

\begin{tabular}{|c|c|c|c|}
\hline No & Kegiatan & Keterangan & Narasumber \\
\hline 1 & $\begin{array}{l}\text { Sosialisasi dan penyamaan persepsi } \\
\text { tentang kegiatan }\end{array}$ & Menentukan target luaran bersama & $\begin{array}{l}\text { Dr. Danner Sagala } \\
\text { Dr. Dodo Sutardi }\end{array}$ \\
\hline 2 & Pelatihan penulisan artikel ilmiah & $\begin{array}{l}\text { Persepsi tentang artikel ilmiah dan } \\
\text { penyusunan draft (dari hasil } \\
\text { penelitian tindakan kelas) }\end{array}$ & $\begin{array}{l}\text { Dr. Dodo Sutardi } \\
\text { Dr. Danner Sagala } \\
\text { Supriyono, M.Pd. }\end{array}$ \\
\hline 3 & $\begin{array}{l}\text { Pendampingan penelaahan draft } \\
\text { artikel }\end{array}$ & $\begin{array}{l}\text { Hasil telaah dikembalikan ke } \\
\text { penulis untuk direvisi, dan } \\
\text { seterusnya hingga siap kirim }\end{array}$ & $\begin{array}{l}\text { Dr. Danner Sagala } \\
\text { Supriyono, M.Pd. }\end{array}$ \\
\hline
\end{tabular}

\section{Pelaksanaan Kegiatan}

Kegiatan dilakukan berdasarkan rencana kerja yang ditetapkan saat persiapan. Pelatihan penulisan artikel ilmiah dilaksanakan dengan sifat partisipatif dimana peserta juga memiliki tugas dan tanggung jawab dalam menulis naskah. Metode yang digunakan saat pelatihan adalah metode ceramah dan metode yang digunakan saat pendampingan adalah metode mentoring. Peserta tidak hanya memperoleh materi saat pelatihan tetapi juga memperoleh pendampingan hingga manuskrip siap dikirim ke jurnal ilmiah tujuan.

\section{Evaluasi Kegiatan}

Evaluasi dilaksanakan untuk menilai persepsi peserta terhadap kegiatan pelatihan dan tingkat partisipasi peserta dalam setiap kegiatan termasuk dalam membuat naskah ilmiah. Data yang dikumpulkan disajikan secara tabulasi dan deskriptif naratif untuk memberikan gambaran dampak dan respon peserta terhadap kegiatan yang dilaksanakan.

\section{HASIL DAN PEMBAHASAN}

\section{Animo dan motivasi guru mengikuti kegiatan}

Jumlah peserta yang mengikuti pelatihan adalah 52 orang guru dari berbagai sekolah, jabatan dan pangkat (Gambar 1, Gambar 2, Gambar 3, Gambar 4). Jumlah peserta tersebut adalah 19\% dari seluruh guru yang ada di Kecamatan Air Periukan Seluma. Data Dirjen Dikdasmen Kemdikbud (2018) menunjukkan bahwa Kabupaten Seluma memiliki 247 sekolah yang tersebar di 14 kecamatan. Sebanyak 20 sekolah di antaranya berada di Kecamatan Air Periukan. Sebanyak 267 orang guru bertugas di sekolah-sekolah yang ada di Kecamatan Air Periukan tersebut. Jumlah peserta tersebut menunjukkan animo yang tinggi untuk mengikuti pelatihan karena melebihi target jumlah peserta yang diperkirakan yaitu 30 orang. Kegiatan ini juga mendapat dukungan dari Pemerintah setempat melalui Dinas Pendidikan dan Kebudayaan Kabupaten Seluma (gambar 5). 
Tingginya animo guru dapat disebabkan oleh efektifitas sosialisasi yang dilakukan oleh pengurus KKG Kecamatan Air Periukan terhadap semua anggotanya. Sosialisasi rencana kegiatan kepada anggota KKG Air Periukan dilakukan dengan baik oleh mitra. Pengurus KKG Kecamatan Air Periukan bekerjasama dengan Musyawarah Kerja Kepala Sekolah Kecamatan Air Periukan dalam sosialisasi kegiatan. Sosialisasi yang baik menghasilkan animo guru yang sangat tinggi untuk mengikuti pelatihan. Calon peserta mengetahui substansi pelatihan yang akan diterima sesuai dengan kebutuhan mereka. Para guru menyadari bahwa mereka memerlukan kemampuan menulis artikel ilmiah agar memperoleh karir kepangkatan yang lebih tinggi.

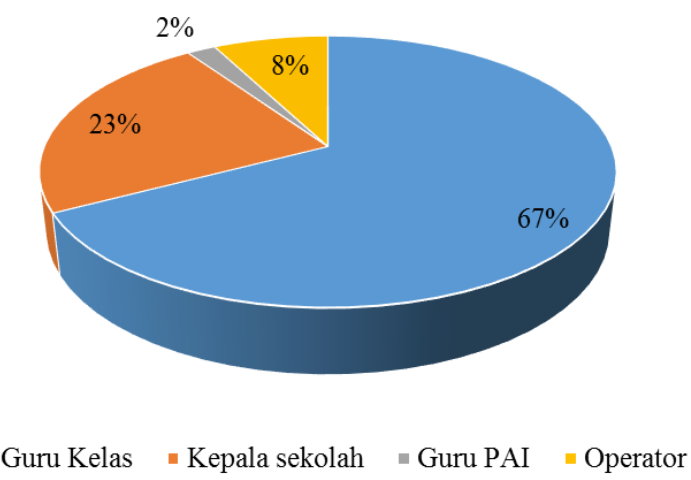

Gambar 1 Jumlah peserta pelatihan dan pendampingan penulisan artikel ilmiah berdasarkan jabatan guru

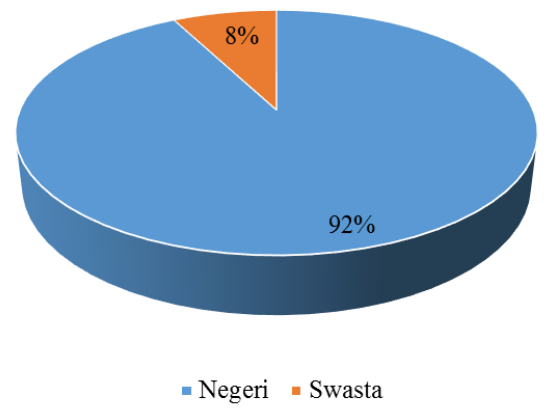

Gambar 2 Jumlah peserta pelatihan dan pendampingan penulisan artikel ilmiah berdasarkan asal sekolah

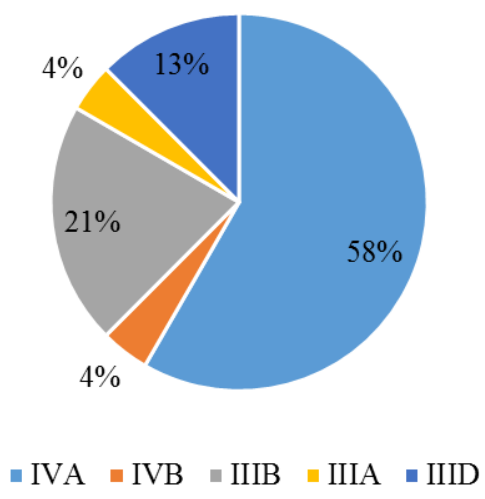

Gambar 3 Perbandingan peserta pelatihan berdasarkan golongan kepangkatan asal sekolah

Kegiatan dimulai dengan penyamaan persepsi bersama pengurus KKG Kecamatan Air Periukan sebagai mitra (Gambar 6). Penyamaan persepsi memiliki korelasi dengan tahapan sosialisasi dan seleksi peserta pelatihan. Kegiatan dirancang berdasarkan hasil penelusuran terhadap permasalahan mitra. Kegiatan dilaksanakan untuk memberikan solusi atas permasalahan utama yang dihadapi oleh mitra sesuai dengan kesepakatan permasalahan prioritas. Oleh 
karena itu, pengurus KKG Kecamatan Air Periukan diberikan gambaran tentang rencana kegiatan meliputi bentuk, tujuan, manfaat dan target kegiatan. Penyamaan persepsi dilakukan agar pelaksana kegiatan dan mitra memiliki kesamaan target capaian luaran. Mitra, yang sudah memiliki kesamaan pandang dan komitmen terhadap target bersama, merancang materi sosialisasi dengan baik sehingga calon peserta memahami tujuan kegiatan. Mitra melakukan sosialisasi kepada seluruh anggota KKG Kecamatan Air Periukan dengan beberapa persyaratan calon peserta pendampingan. Penentuan persyaratan peserta pendampingan bertujuan untuk efektivitas pendampingan demi tercapainya target.

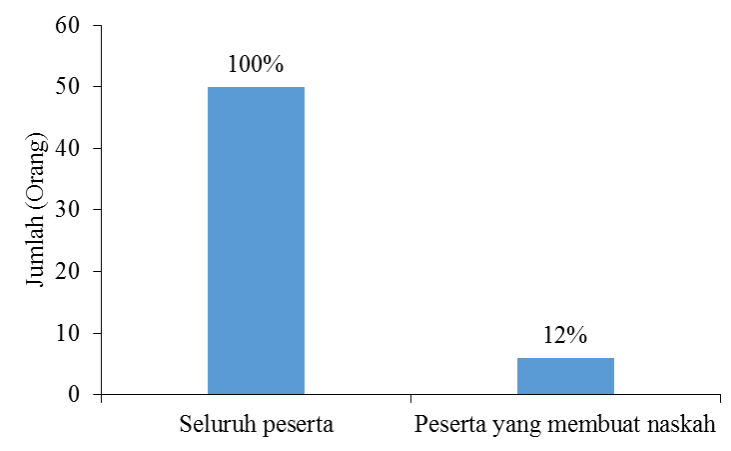

Gambar 4 Perbandingan jumlah seluruh peserta dengan peserta yang membuat naskah untuk didampingi

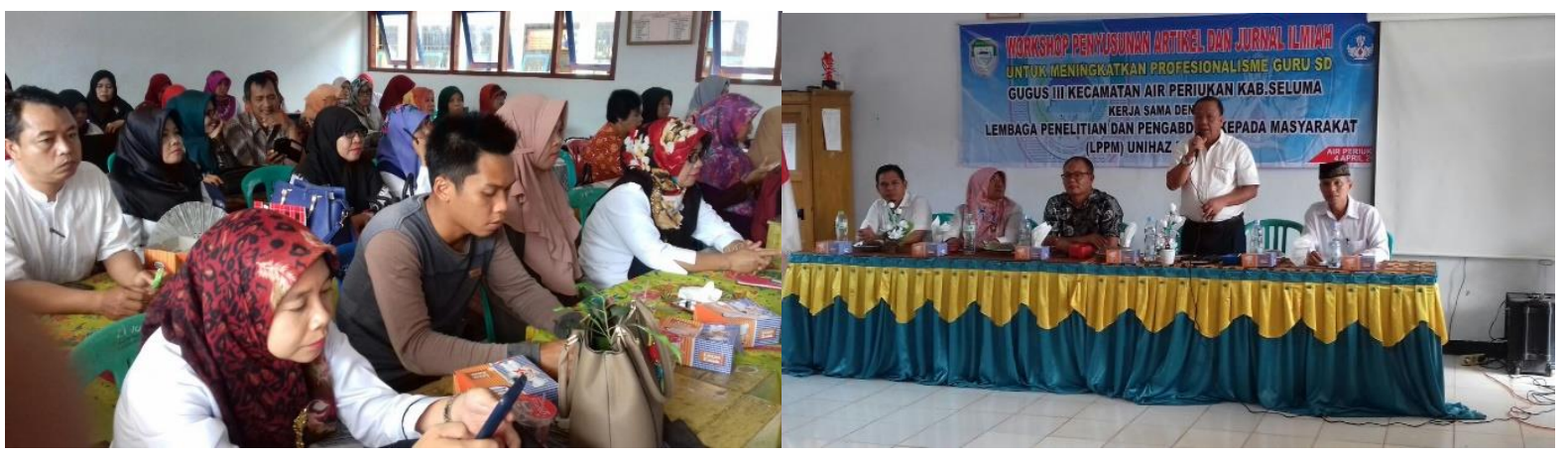

Gambar 5 Pembukaan kegiatan pelatihan oleh Kepala Dinas Pendidikan dan Kebudayaan Kabupaten Seluma

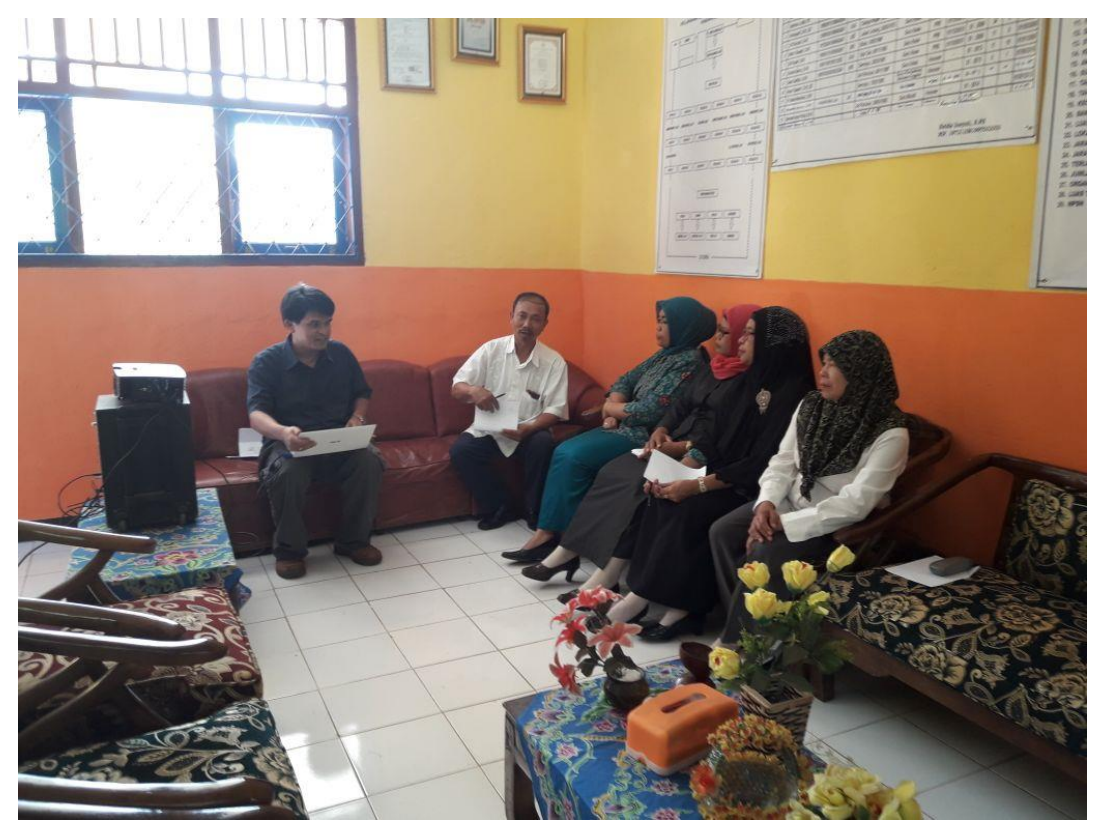

Gambar 6 Penyamaan persepsi bersama pengurus KKG Air Periukan sebagai mitra kegiatan 
Kehadiran para kepala sekolah mengikuti kegiatan pelatihan (Gambar 1) menunjukkan bahwa pelatihan penulisan artikel ilmiah perlu diberikan pada guru bahkan guru yang menjabat kepala sekolah. Pada umumnya kepala sekolah dijabat oleh guru yang sudah memiliki pangkat pembina (IVA). Persyaratan wajib kenaikan pangkat dari IVA ke IVB adalah artikel ilmiah yang telah dipublikasikan pada jurnal ilmiah. Beberapa guru yang belum memiliki pangkat IVA juga mengikuti kegiatan pelatihan dan pendampingan ini. Sebanyak 38\% peserta adalah guru dengan pangkat di bawah IV yaitu IIIA, IIIB, dan IIID (Gambar 3). Keikutsertaan peserta yang masih memiliki pangkat di bawah IVA melihat bahwa persyaratan publikasi artikel ilmiah harus dipenuhi saat mereka telah pada pangkat IVA dan akan naik ke IVB.

Motivasi yang mendorong tingginya animo para guru di lingkungan KKG Kecamatan Air Periukan untuk mengikuti kegiatan pelatihan adalah persoalan kepangkatan meskipun ada peserta yang ikut pelatihan bukan dengan motivasi kepangkatan yaitu guru yang berasal dari sekolah swasta (Gambar 2). Namun, sebanyak 92\% peserta berasal dari sekolah negeri yang sangat terkait dengan syarat publikasi artikel ilmiah untuk kenaikan pangkat. Motivasi yang demikian menurut Dhermawan et al. (2012) dan Suwati (2013) adalah lazim karena jenjang karir seorang karyawan akan menentukan penghasilan dan peningkatan penghasilan menjadi motivasi seorang karyawan dalam bekerja secara profesional. Selemani-Meke (2013) memasukkan faktor gaji dan tunjangan sebagai salah satu faktor yang menentukan motivasi guru dalam pengembangan keprofesian berkelanjutan dalam rangka meningkatkan kualitas kelas.

\section{Persepsi guru dan ketercapaian luaran kegiatan}

Pelatihan penulisan artikel ilmiah yang direncanakan dilaksanakan sebanyak 2 kali pertemuan dilakukan penyesuaian berdasarkan kebutuhan. Pelatihan dan pendampingan penulisan artikel ilmiah dilaksanakan sebanyak 3 pertemuan. Pertemuan pertama dan kedua dilaksanakan dalam bentuk ceramah dan diskusi. Narasumber memberikan informasi-informasi tentang penulisan artikel ilmiah untuk publikasi di jurnal ilmiah. Topik pertemuan pertama adalah menyusun dan mengolah data hasil penelitian tindakan kelas menjadi manuskrip ilmiah. Tema pada pertemuan kedua adalah mempersiapkan manuskrip artikel ilmiah hingga siap dikirim ke jurnal ilmiah. Pertemuan ketiga dilaksanakan dalam bentuk pendampingan. Peserta yang sudah memiliki data, misalnya hasil penelitian tindakan kelas, diberi tugas untuk menuliskan manuskrip (draft) artikel ilmiah. Draft dikirim lewat email kepada narasumber paling lambat satu hari sebelum pertemuan ketiga. Semua manuskrip yang sudah dikirim dan sudah ditelaah oleh narasumber dibahas dan dijelaskan pada pertemuan ketiga. Kegiatan pada pertemuan ketiga adalah bedah manuskrip. Penulisan artikel ilmiah tidak cukup dengan mendengarkan materi tentang penulisan artikel ilmiah yang baik. Penulisan artikel ilmiah harus dilatih dan dilakukan secara terus menerus. Praktek ini sesuai dengan pendapat Ecarnot et al. (2015) dan Hoogenboom dan Manske (2012) yang menyatakan bahwa menulis artikel ilmiah memerlukan upaya yang serius dan latihan berulang.

Naskah yang ada untuk didampingi pada pertemuan ketiga berjumlah 6 judul dari 6 orang peserta (Gambar 4). Animo yang tinggi untuk mengikuti pelatihan belum diikuti dengan jumlah naskah yang banyak. Dalam sosialisasi mitra terhadap calon peserta sudah disampaikan bahwa luaran kegiatan adalah naskah untuk dikirim ke jurnal ilmiah. Sebagian besar calon peserta yang ditindaklanjuti untuk mengikuti kegiatan ini adalah calon peserta yang telah memiliki bahan baku untuk ditulis menjadi manuskrip ilmiah. Bahan manuskrip dapat berupa laporan penelitian tindakan kelas.

Informasi dari peserta saat pertemuan pertama ketika ditanyakan apakah memiliki bahan baku karya tulis ilmiah adalah bahwa sebagian besar peserta telah memiliki laporan hasil penelitian tindakan kelas yang selama ini memang dilaksanakan untuk menghasilkan karya tulis ilmiah. Namun, para guru belum terlatih menuliskan laporan hasil penelitian tindakan kelas menjadi suatu manuskrip ilmiah yang siap dikirimkan ke jurnal ilmiah. Selain itu, Farisi (2011) menuliskan fakta-fakta tentang guru yang salah satunya adalah persepsi guru tentang publikasi artikel ilmiah pada jurnal ilmiah. Para guru memiliki persepsi bahwa mempublikasi artikel ilmiah pada jurnal ilmiah sangat sulit bahkan menjadi "momok" bagi guru. Dapat diringkas bahwa ketidakbiasaan guru mempublikasikan artikel ilmiah pada jurnal ilmiah membuat kegiatan profesi ini menjadi momok bagi guru.

Hasil penelitian Noorjannah (2014) menunjukkan bahwa usia mempengaruhi kemampuan guru dalam penulisan karya tulis ilmiah. Penelitian ini mengklasifikasikan usia guru 39-47 tahun dan 51-58 tahun. Guru dengan usia 51-58 tahun lebih mengalami kesulitan menulis artikel ilmiah dibandingkan usia 39-47 tahun. Sementara guru pada usia yang lebih muda atau pada kenaikan pangkat awal (IIIA hingga IVA) tidak dituntut diwajibkan menghasilkan publikasi artikel ilmiah. 
Persepsi guru tentang kesulitan mempublikasikan artikel ilmiah menyebabkan ketercapaian luaran kegiatan ini tidak maksimal. Jumlah naskah yang didampingi dalam bentuk mentoring hanya $12 \%$ dari jumlah semua peserta yang mengikuti pelatihan dan pendampingan (Gambar 4). Pertemuan ketiga tetap dilaksanakan dengan membedah keenam naskah yang ada. Naskah telah ditelaah oleh narasumber sebelum pertemuan ketiga. Semua peserta melihat dan mendengarkan bedah artikel terhadap keenam naskah yang ada. Narasumber menjelaskan hal-hal yang sudah baik dan yang belum baik dari semua naskah yang dikumpulkan oleh peserta.

Pendampingan atau mentoring sangat membantu peserta untuk lebih memahami penulisan artikel ilmiah. Peserta mengetahui kelemahan dan kektuatan yang sudah dimiliki dalam draft/manuskrip yang ditulis. Pendamping/narasumber membedah manuskrip tersebut setelah sebelumnya dibaca oleh pendamping. Peserta dapat langsung memperbaiki manuskrip yang masih perlu perbaikan. Ini merupakan kelebihan metode pandampingan dibandingkan hanya pelatihan. Aisyah dan Mahanani (2017) menyatakan bahwa perlu program berkelanjutan dalam melatih para guru untuk mampu menulis artikel ilmiah untuk publikasi pada jurnal. Pendampingan atau mentoring merupakan salah satu bentuk dari program berkelanjutan tersebut.

\section{KESIMPULAN}

Publikasi artikel ilmiah pada majalah/jurnal ilmiah merupakan salah satu faktor penghambat karir kepangkatan guru karena guru tidak terbiasa dalam mempublikasikan hasil penelitian pada jurnal ilmiah peer-reviewed. Ketidakbiasaan publikasi artikel ilmiah menyebabkan publikasi ilmiah menjadi "momok" dan membentuk ketidakpercaya-dirian guru untuk mempublikasikan artikel ilmiah. Oleh karenanya, para guru memiliki keinginan mengetahui dan dilatih dalam mempublikasikan artikel ilmiah pada jurnal ilmiah. Namun, belum banyak yang langsung dapat membuat naskah untuk didampingi hingga siap dikirim ke jurnal ilmiah. Pelatihan dan pendampingan publikasi artikel ilmiah perlu tetap dilaksanakan agar para guru terbiasa dalam menulis artikel ilmiah karena publikasi artikel ilmiah menjadi persyaratan wajib bagi guru untuk kenaikan pangkat dari IVA ke IVB. Pendampingan sangat membantu para guru dalam menulis artikel ilmiah.

\section{UCAPAN TERIMA KASIH}

Kegiatan pengabdian pada masyarakat ini didanai oleh Universitas Prof. Dr. Hazairin, SH melalui Lembaga Penelitian dan Pengabdian pada Masyarakat dengan Surat Perjanjian Nomor 34/A-5/LPPM-UNIHAZ/III/2018.

\section{DAFTAR PUSTAKA}

Aisyah, E. N., \& Mahanani, P. (2017). Pelatihan menulisan artikel ilmiah bagi Guru Sekolah Dasar dan Taman KanakKanak Kecamatan Tajinan Kabupaten Malang. Abdimas Pedagogi: Jurnal Ilmiah Pengabdian kepada Masyarakat, 1(1), 22-26.

Bem, D. J. (2003). Writing the empirical journal article. Di dalam J. M. Darley, M. P. Zanna, \& H. L. Roediger III (Ed.), The Compleat Academic: A Practical Guide for the Beginning Social Scientist (Second). Washington: American Psychological Association.

Dhermawan, A. A. N. B., Sudibya, I. G. A., \& Utama, I. W. M. (2012). Pengaruh motivasi, lingkungan kerja, kompetensi, dan kompensasi terhadap kepuasan kerja dan kinerja pegawai di lingkungan Kantor Dinas Pekerjaan Umum Provinsi Bali. Jurnal Manajemen, Strategis Bisnis, dan Kewirausahaan, 6(2), 173-184.

Dirjen Dikdasmen Kemdikbud. (2018). Data Sekolah Kab. Seluma - Dapodikdasmen. Diambil 13 Februari 2018, dari http://dapo.dikdasmen.kemdikbud.go.id/sp/2/260800

Ecarnot, F., Seronde, M.-F., Chopard, R., Schiele, F., \& Meneveau, N. (2015). Writing a scientific article: A step-bystep guide for beginners. European Geriatric Medicine, 6(6), 573-579. https://doi.org/10.1016/j.eurger.2015.08.005

Farisi, M. I. (2011). Fakta-fakta penelitian tentang profesi guru dan pengembangan profesi guru. Interaksi: Jurnal Kependidikan, 6(5), 1-8.

Hoogenboom, B. J., \& Manske, R. C. (2012). How to write a scientific article. International Journal of Sports Physical Therapy, 7(5), 512-517.

Ilfiandra, Suherman, U., Akhmad, S. N., Budiamin, A., \& Setiawati. (2016). Pelatihan dan pendampingan penulisan karya tulis ilmiah bagi guru SD. Jurnal Pengabdian pada Masyarakat, 1(1), 70-81. 
Ismail, M. I. (2010). Kinerja dan kompetensi guru dalam pembelajaran. Lentera Pendidikan: Jurnal Ilmu Tarbiyah dan Keguruan, 13(1), 44-63.

Noorjannah, L. (2014). Pengembangan profesionalisme guru melalui penulisan karya tulis ilmiah bagi guru profesional di SMA Negeri 1 Kauman Kabupaten Tulungagung. Jurnal Humanity, 10(1), 97-114.

Nurhayati, A. (2015). Penguatan kompetensi guru fisika MTs/SMP/MA/SMA Se-Kecamatan Ngaliyan melalui pelatihan penulisan artikel ilmiah sebagai salah satu upaya peningkatan kuantitas kontributor jurnal pendidikan MIPA. Dimas: Jurnal Pemikiran Agama untuk Pemberdayaan, 15(2), $135-150$. https://doi.org/10.21580/dms.2015.152.750

Selemani-Meke, E. (2013). Teacher motivation and implementation of continuing professional development programmes in Malawi. Anthropologist, 15(1), 107-115.

Suwati, Y. (2013). Pengaruh kompensasi dan motivasi kerja terhadap kinerja karyawan pada PT. Tunas Hijau Samarinda. eJournal Ilmu Administrasi Bisnis, 1(1), 41-55. 